\title{
Incidence of Viruses in Two Large-Scale Plantings of Blackberry in South Carolina as Detected Through the Use of Sentinel Plants and RT-PCR
}

Bindu Poudel, Department of Biological Sciences, Clemson University, Clemson SC 29634-0314, and University of Florida, IFAS, Tropical Research and Education Center, Department of Plant Pathology, Homestead, 33031-3314 (current address); Philip Rollins, Clemson University, Spartanburg County Extension Office, Spartanburg, SC 29369; and David T. Bishop and Simon W. Scott, ${ }^{\dagger}$ Department of Biological Sciences, Clemson University, Clemson SC 29634-0314

Accepted for publication 21 December 2017.

\section{Abstract}

Some plants in two large-scale blackberry plantings established from virus-indexed planting material displayed symptoms typical of virus infection in the early days of the growing season immediately after planting. Groups of sentinel plants exposed within the plantings for 30-day periods over additional growing seasons, and subsequently screened for the presence of five viruses by reverse transcription PCR, detected Blackberry yellow vein-associated virus (BYVaV), Blackberry virus Y (BVY), Blackberry chlorotic ringspot virus (BCRV), Blackberry virus $E$ (BVE), and Blackberry leaf mottle-associated virus (BLMaV). Because these viruses are thought to be transmitted through the actions of arthropods, and bearing in mind that the plantings had been established with virus-indexed material, it seems that the viruses must be moving into the new crops from adjacent native vegetation and once established moving freely within the crops. BYVaV has been reported from South Carolina previously. A recent publication reports the detection of BLMaV in samples originating from South Carolina and demonstrates transmission of the virus by mites. This is the first report of the detection of $B C R V, B V Y$, and BVE within the state and provides support for the movement of the latter two viruses (BVY and BVE) within established plantings of blackberry as a result of vector activity.
Blackberry cultivation in the southeastern United States is flourishing with the release of new cultivars producing fruits suitable for the fresh market and the corresponding increase in demand by consumers for fresh produce. Viral infections are of serious concern for blackberry growers because the plant is affected by a number of viruses (Martin et al. 2013). The plants are clonally propagated; thus, it is recommended that new plantings should be established using proven sources of virus-indexed material. The costs associated with the establishment of a new planting can exceed $\$ 10,000$ per acre (https://rubus.ces.ncsu.edu/rubusblackberry-and-raspberry-budgets-pricing/). Because blackberry is a biennial crop, growers have to wait for at least 2 years to obtain a full harvest, and viral infections can reduce the commercial life expectancy of a planting from 15 to 20 years to 5 to 7 years or less. With the knowledge that virus infection may significantly reduce the economic life expectancy of the plantings, the producers began to question the anticipated profit margins and financial returns on which they had based their decision to grow the crop. In short, they wanted to know how viruses entered a crop established with virusindexed material and if these viruses were spreading throughout the crop.

Sentinel plants have been used to detect viral infections and peaks of vector activity in crops (Wosula et al. 2013). They typically act as sensitive indicators of some problem that is not immediately apparent. In addition, they may act as "bait" plants designed to attract

${ }^{\dagger}$ Corresponding author: Simon W. Scott; E-mail: sscott@clemson.edu

(C) 2018 The American Phytopathological Society vectors of some agent and, once infected, allow the agent to replicate to levels that are detectable using other techniques (for example enzyme linked immunosorbent assay [ELISA] and polymerase chain reaction [PCR]). In this work, the sentinel plants provided young plant tissue that was potentially attractive to possible arthropod vectors. In addition, these plants constituted a source of tissue that could be removed from the field and allowed to continue to develop for later examination, providing the optimum chance of detecting a vector-inoculation event of a specific virus. PCR was used for virus detection because none of the viruses for which we were proposing to test can be detected by ELISA. After the detection of Blackberry yellow vein disease in blackberry in the southeastern United States, Susaimuthu et al. (2007) used a small number of sentinel plants to understand the movement of the crinivirus Blackberry yellow vein-associated virus (BYVaV) and the brambyvirus Blackberry virus $Y$ (BVY). Here we used a large number of sentinel plants as a means of defining samples for PCR assays to detect five viruses in some 69 acres of blackberry plants over three growing seasons and at two locations.

\section{Survey Locations, Sampling Procedure, and PCR Testing}

Two commercial, relatively large, plantings of blackberry were established in South Carolina in 2010 using virus-indexed source material. James Cooley's farm is located in Chesnee, SC, and has 40 acres of blackberries ( 35 acres of cv. 'Natchez' and 5 acres cv. 'Ouachita'). Jose Landa's farm, the Double J, is located in Enoree, $\mathrm{SC}$, and has 29 acres of blackberries ( 7 acres of cv. 'Navaho', 8 acres of cv. 'Prime Ark45', and 14 acres of cultivars 'Von', 'Osage', and 'Natchez' combined). The two plantings are 35 miles apart, 
differ in elevation by 170 feet, are at the northern and southern extremes of Spartanburg County, SC, respectively, and are remote from any other commercial blackberry plantings. However, plants showing symptoms typical of viral infection in blackberry (Martin et al. 2013) were observed in the growing season immediately after planting (2010) at both locations and became widespread in the plantings in subsequent seasons.

Plants of two blackberry cultivars, Natchez and Ouachita, propagated from virus-indexed mother plants through tissue culture, were obtained from North American Plants, McMinnville, OR, at the start of each growing season to act as sentinel plants. The plants were medium-sized transplants grown in $1-1 / 2$ in. wide by 2 in. deep paper plugs and between 6 and 12 in. in height. They could be transplanted directly to the field if so desired (http://www. naplants.com/page.asp?id=8). However, for our work the plants were established in $5 \mathrm{in}$. pots for 1 month and maintained in a screened greenhouse before being exposed in the field. Prior to exposure in the field, plants were tested by reverse transcription PCR (RT-PCR) for the viruses being investigated in the study. In 2012, a total of 300 sentinel plants (150 of each cultivar) were exposed in groups of five for a period of 30 days at 10 sites in location 1 (Cooley's farm) during each of the months from June through August. In 2013 and 2014, a total of 480 sentinel plants (240 of each cultivar) were exposed in groups of three for a period of 30 days at 10 sites in both location 1 and location 2 (Double J) during each of the months from May through August. The plants were located adjacent to the end of existing rows of blackberry plants within the main body of the planting. This allowed us to use the planting's irrigation system as a water supply during exposure but sample from the interior of the crops rather than the margins, where results might be influenced by the proximity of native vegetation. After exposure, plants were treated with a foliar $(0.1 \%$ bifenthrin, Up-Star Gold) as well as a systemic (1.25 g/gallon, Merit $75 \mathrm{WP}$, Bayer) insecticide before being returned to the greenhouse and allowed to overwinter as dormant material. Samples for virus indexing of exposed sentinel plants by RT-PCR were collected from the young, fully expanded leaves of new growth in the following spring (late March). Total nucleic acids (TNA) were extracted and
RT-PCR completed using methods described previously (Poudel et al. 2013). In addition to the TNA samples from sentinel plants, positive controls for the viruses (supplied by Ioannis Tzanetakis, University of Arkansas) and controls from known noninfected plants were included in each group of assays. The PCR products were visualized in $1.5 \%$ agarose gels buffered with $1 \times$ Tris/borate/ EDTA buffer and stained with GelRed (Phenix Research). The specific primer pairs used to detect each virus are shown in Table 1. Amplicons of the size anticipated for each virus were extracted from the gels, cloned into a pGem vector (Promega), and sequenced (Sanger dideoxy sequencing) using M13F and M13R primers. The resulting sequences were subject to BLAST searches at the National Center for Biotechnology Information to confirm that the sequence of the products was identical to the sequences held in GenBank for the specific viruses. Multiple alignments of the sequences of seven amplicons for each virus were created using Mega 6 (Tamura et al. 2013), and the consensus sequence was deposited in GenBank. The accession numbers provided for these sequences are shown in Table 1. In all cases, the sequences of the amplicons showed $>98 \%$ nucleotide identity with the reference sequences held in GenBank.

The number of sentinel plants in which each of the five viruses was detected using PCR is shown in Table 2. Virus-like symptoms (distinct line patterns) were seen in a few sentinel plants as early as 4 weeks after being exposed in the field, although, most commonly, no symptoms were expressed until after the plants had emerged from dormancy following overwintering in the greenhouse, and not all sentinel plants in which viruses were detected by PCR displayed symptoms. There did not appear to be any relationship between a specific virus and a specific symptom. Not unexpectedly, as has been shown by previous research (Susaimuthu et al. 2007, 2008), $\mathrm{BYVaV}$ was detected both in some plants that were asymptomatic and in others that were symptomatic. The latter symptomatic infections indicated the presence of more than one virus, and the number of plants in which two or more of the viruses for which we were testing (mixed infections) were detected is shown in Table 3.

There are clear differences between the numbers of sentinel plants in which the viruses were detected at the two sites and differences in incidence among the five viruses over different months

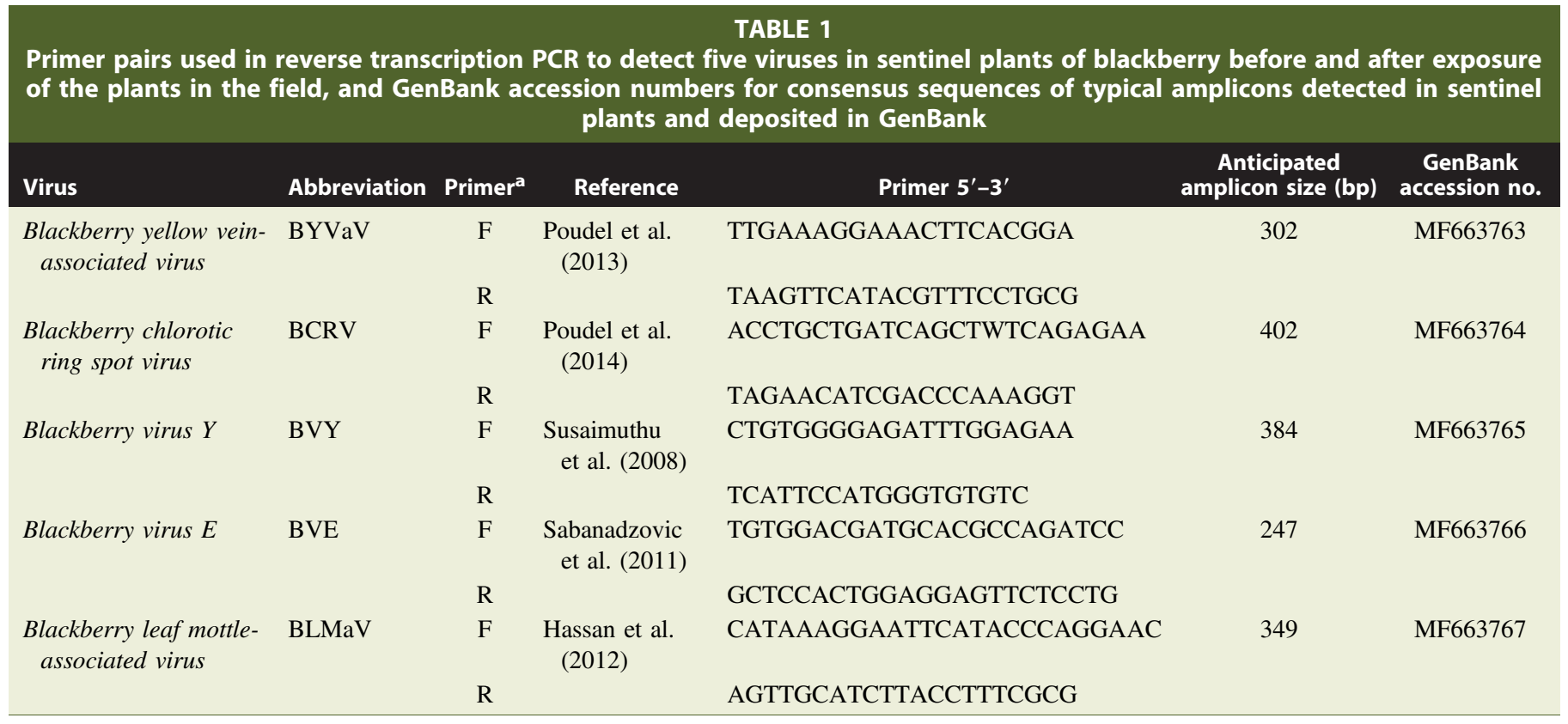

${ }^{\mathrm{a}} \mathrm{F}=$ forward, and $\mathrm{R}=$ reverse. 
TABLE 2

Incidence of five viruses detected in sentinel plants exposed during the growing seasons at either Cooley's Farm (2012, 2013, and 2014) or the Double J Ranch (2013 and 2014)a

Virus May June July August Total

Cooley's

2012

BYVaV

BVY

BCRV

BVE

BLMaV

Total infections

Sentinel plants

2013

BYVaV

BVY

BCRV

BVE

BLMaV

Total infections

Sentinel plants

2014

BYVaV

BVY

BCRV

BVE

BLMaV

Total infections

Sentinel plants

Double J

2013

BYVaV

BVY

BCRV

BVE

BLMaV

Total infections

Sentinel plants

2014

BYVaV

BVY

BCRV

BVE

BLMaV

Total infections

Sentinel plants

${ }^{\text {a }}$ Detections were made using reverse transcription PCR and the primers listed in Table 1. Virus abbreviations are listed in Table 1. Numbers indicate the number of plants in which the specific virus was detected by PCR after exposure during the month indicated, the total number of infections of specific viruses detected by PCR in that month, and the number of sentinel plants placed in the field and exposed to vector activity during the month.

of the growing season. In 2012, at Cooley's, over 50\% of the sentinel plants in which viruses were detected had been exposed during the month of July, with detections of BYVaV (11) being the most frequent. Again in 2013 at Cooley's, almost 50\% of the plants in which viruses were detected had been exposed during the month

TABLE 3

Number of sentinel plants in which more than one virus was detected during the growing seasons at either Cooley's Farm $(2012,2013,2014)$ or the Double J Ranch $(2013$ and 2014)

Year

2012

2013

2014

a Detections were made using reverse transcription PCR and the primers listed in Table 1.

of July, but in this year detections of Blackberry leaf mottleassociated virus (BLMaV) (16) were the most frequent, with detections of Blackberry virus E (BVE) (8) in August making up the second largest group. In 2014 at Cooley's, the greatest number of infected plants detected (33) was again for BLMaV but in June, and the second largest number of infections detected (12) was for BYVaV in the month of July. In 2013 at the Double J, the peak of detection for BYVaV (19) occurred in May. A peak of detection for BLMaV (14) occurred in July, and a peak of detection for BVE (11) occurred in August. In 2014 at the Double J, the greatest number of infected plants detected was for BLMaV but in the month of May.

\section{Implications for Control of Virus Infections in Blackberry in South Carolina}

We had been unable to detect any of the five viruses for which we proposed to test in the sentinel plants when received from the producer and before exposure in the field. That the crops had been established initially using virus-indexed material allowed us to presume that the viruses had moved from reservoir hosts within the native vegetation adjacent to the plantings. The detection of the viruses in sentinel plants would support the idea that there is movement of virus into the sentinel plants from sources within the crop, even though there was no direct contact between the crop plants and the sentinel plants. The plantings had been in the field for some 2 to 3 years before we began our experiments and had time to acquire viruses. Thus, we cannot provide definitive support for the movement of the viruses from native vegetation. However, it must be noted that wild blackberry does make up a portion of the native vegetation and must constitute a potential reservoir for viruses to move into commercial plantings. Blackberry chlorotic ringspot virus (BCRV) is an ilarvirus; thus, the method of transmission is recognized as being through wind-blown pollen and the feeding of thrips, as in case of Prune dwarf virus, Prunus necrotic ringspot virus (Greber et al. 1992), and Tobacco streak virus (Sdoodee and Teakle 1993). The remaining four viruses are all known, or inferred, to have arthropod vectors. BYVaV is a crinivirus. Other members of that genus are transmitted by whiteflies. BVY is the sole member of the genus Brambyvirus in the family Potyviridae. Potyvirids are transmitted by a range of vectors including aphids and mites. BVE is related to viruses in the genus Allexivirus that infect species in the family Alliaceae and are transmitted by mites (Kang et al. 2007). Emaraviruses (BLMaV) are transmitted by mites (Mielke-Ehret and Mühlbach 2012; Tatineni et al. 2014), and recent work (Hassan et al. 2017) has demonstrated transmission of BLMaV by mites. Whiteflies, aphids, and mites were all present in both plantings of blackberry, although no data on the abundance of these putative vectors over time were recorded. However, it is distinctly possible that the month in which the peak number of infected plants was detected related to maximum periods of vector activity and movement. Such movement may have been deliberate- the vector 
moving from one host plant to another as part of their life cyclesor may result from either passive movement owing to wind and/or a rapidly increasing population forcing members to seek new host plants. The two sites were 35 miles apart and differed in elevation by 170 feet, so clearly localized differences in climate may have contributed to differences in vector activity. Equally, the more diverse range of blackberry cultivars at the Double $\mathrm{J}$ may have affected the vector populations.

As previously stated, viral infections are of serious concern for blackberry growers, and the occurrence of viruses in plantings established using virus-indexed material raised questions about the validity of the economic model (anticipated profit margins and financial returns) on which they had based their decision to plant blackberry. Although our preliminary research has identified some of the viruses that are affecting blackberry plantings in South Carolina, extensive additional research is needed (i) to identify the entire spectrum of viruses that may be involved, (ii) to elucidate the epidemiology of the viruses involved both as individuals and as mixed infections, and (iii) to provide information that would potentially allow growers to address the problem. Because four of the viruses detected either have known, or are inferred to have, arthropod vectors, the use of pesticides to control viral spread and damage must be considered. However, differences in the months in which the peak numbers of a virus were detected, and by inference periods during which maximum vector activity occurred, make designing a generally applicable spray schedule difficult, particularly when the periods of vector activity differ so markedly at locations separated by less than 40 miles. For example, in 2013 at Cooley's farm the peak month for the detection of BLMaV was July. In 2014, the peak month for detection of BLMaV was June. Although a peak of BLMaV detection occurred at the Double $\mathrm{J}$ in July 2013, in 2014 this virus was most frequently detected in May. In addition, the timing of the application of insecticidal sprays in relation to the harvesting of fruit is critical. Freshly harvested blackberries are sold at a premium, which may be adversely affected if sprays to control vectors of viruses need to be applied near to fruit harvest.

Over time, numerous new viruses have been detected in blackberry plants (Martin et al. 2013). Some are newly described viruses, whereas others have been previously described in other crops but are new to blackberry plants, and there is little information about the epidemiology of viruses in blackberry plantings. The detection of the viruses in the sentinel plants clearly indicates that the viruses are being moved around within the field by vectors. Because the material used to initiate the plantings was virus indexed but began to display symptoms typical of viral infection within weeks of being planted in the field, the suggestion is that the viruses identified must initially have moved in from native vegetation. The recent report (Hassan et al. 2017) in which BLMaV was detected in $64 \%$ of samples from South Carolina also detected the virus in $59 \%$ of samples of wild blackberry collected from Arkansas. This suggests the possibility of wild blackberry being both the original source of this virus in these infections in South Carolina and a reservoir host for the mite vectors. The viruses were detected in sentinel plants in each growing season; thus, the vectors were clearly established in the crop and were actively transmitting viruses. The increased incidence of viruses detected in some months suggests either that peaks of activity occur at some stage during the life cycle of the vector or that the blackberry host plant is more susceptible during these growth stages.

Thus, although the use of virus-indexed planting material is an optimal, and essential, first step in dealing with a virus in a longlived crop, other factors must be considered if attempts to manage the impact of virus infections associated with arthropod vectors are to be made. In this work, we detected three viruses not previously recorded in South Carolina. The detection of the viruses in sentinel plants exposed for relatively brief periods indicates that they are being moved within the crop through the action of vectors. In this situation, the use of methods to manage vector populations and minimize virus transmission (possibly insecticides) seems applicable in order to maximize both yields and planting longevity. Furthermore, the potential reservoirs for the viruses (possibly wild blackberry) that moved into the virus-indexed plants used to establish these plantings need to be confirmed so that measures to control or eliminate these reservoirs can be taken prior to the establishment of additional new blackberry plantings.

\section{Literature Cited}

Greber, R. S., Teakle, D. S., and Mink, G. I. 1992. Thrips-facilitated transmission of prune dwarf and Prunus necrotic ringspot viruses from cherry pollen to cucumber. Plant Dis. 76:1039-1041.

Hassan, M., Di Bello, P. L., Keller, K. E., Martin, R. R., Sabanadzovic, S., and Tzanetakis, I. E. 2017. A new, widespread emaravirus discovered in blackberry. Virus Res. 235:1-5.

Hassan, M., Sabanadzovic, S., Keller, K., Martin, R., and Tzanetakis, I. 2012. A putative new emaravirus associated with blackberry yellow vein disease. Petria 22:354-358.

Kang, S. G., Koo, B. G., Lee, E. T., and Chang, M. U. 2007. Allexivirus transmitted by eriophyid mites in garlic plants. J. Microbiol. Biotechnol. 17: 1833-1840.

Martin, R., MacFarlane, S., Sabanadzovic, S., Quito, D. F., Poudel, B., and Tzanetakis, I. E. 2013. Viruses and virus diseases of Rubus. Plant Dis. 97: 168-182.

Mielke-Ehret, N., and Mühlbach, H. 2012. Emaravirus: A novel genus of multipartite negative strand RNA plant viruses. Viruses 4:1515-1536.

Poudel, B., Ho, T., Laney, A., Khadgi, A., and Tzanetakis, I. E. 2014. Epidemiology of Blackberry chlorotic ringspot virus. Plant Dis. 98:547-550.

Poudel, B., Wintermantel, W. M., Cortez, A. A., Ho, T., Khadgi, A., and Tzanetakis, I. E. 2013. Epidemiology of Blackberry yellow vein-associated virus. Plant Dis. 97:1352-1357.

Sabanadzovic, S., Abou Ghanem-Sabanadzovic, N., and Tzanetakis, I. E. 2011. Blackberry virus E: An unusual flexivirus. Arch. Virol. 156:1665-1669.

Sdoodee, R., and Teakle, D. S. 1993. Studies on the mechanism of transmission of pollen-associated tobacco streak ilarvirus virus by Thrips tabaci. Plant Pathol. 42:88-92.

Susaimuthu, J., Geregrich, R. C., Bray, M. M., Clay, K. A., Clark, J. R., Tzanetakis, I. E., and Martin, R. R. 2007. Incidence and ecology of Blackberry yellow vein-associated virus. Plant Dis. 91:809-813.

Susaimuthu, J., Tzanetakis, I. E., Geregrich, R. C., and Martin, R. R. 2008. A member of a new genus in the Potyviridae infects Rubus. Virus Res. 131: $145-151$

Tamura, K., Stecher, G., Peterson, D., Filipski, A., and Kumar, S. 2013. MEGA6: Molecular Evolutionary Genetics Analysis version 6.0. Mol. Biol. Evol. 30:2725-2729.

Tatineni, S., McMechan, A. J., Wosula, E. N., Wegulo, S. N., Graybosch, R. A., French, R., and Hein, G. L. 2014. An eriophyid mite-transmitted plant virus contains eight genomic RNA segments with unusual heterogeneity in the nucleocapsid protein. J. Virol. 88:11834-11845.

Wosula, E. N., Davis, J. A., Clark, C. A., Smith, T. P., Arancibia, R. A., Musser, F. R., and Reed, J. T. 2013. The role of aphid abundance, species diversity, and virus titer in the spread of sweetpotato potyviruses in Louisiana and Mississippi. Plant Dis. 97:53-61. 